\title{
Introduction to the symposium on critical adult education in food movements: learning for transformation in and beyond food movements - the why, where, how and the what next?
}

\author{
C. R. Anderson ${ }^{1}$ (D) $\cdot$ R. Binimelis ${ }^{2} \cdot$ M. P. Pimbert ${ }^{1} \cdot$ M. G. Rivera-Ferre ${ }^{2}$
}

Accepted: 25 April 2019 / Published online: 15 May 2019

(c) Springer Nature B.V. 2019

Many social movements, peasant organisations and radical educators have been deeply engaged in education for food system transformation for a relatively long time. In contrast, scholarly work on the possible role of pedagogy in radically transforming food systems is more recent. But this field of inquiry is growing as new insights for theory and practice are emerging - especially in the agroecology literature. This symposium of Agriculture and Human Values is timely because it focuses on new research on the importance of critical education for the spread of food sovereignty and agroecology to more people and places. It pays particular attention to the important role that learning, education and pedagogy can play in social transformation for food sovereignty and justice-a tradition that we refer to broadly as "Learning for Transformation". It draws together 7 articles that offer new critical insights about why, where, and how learning for transformation is being implemented,- - and what next. In this editorial introduction, we reflect on how the different educational processes and methods presented here point to a range of possibilities and challenges for social movements.

\section{The why: critical education in an era of multiple crises}

Writing about the decline of reason in everyday life, Stanley Aronowitz highlighted 40 years ago the dangers of a citizenry that lacks the capacity for critical thought, "The issue is the capacity for theoretical or conceptual thought

C. R. Anderson

colin.anderson@coventry.ac.uk

1 Centre for Agroecology, Water and Resilience, Coventry University, Priory Street, Coventry CV1 5FB, UK

2 Agroecology and Food Systems Chair, Inclusive Societies, Policies and Communities Group, University of Vic-Central University of Catalonia, 08500 Vic, Spain itself. When people lack such competence, social action that transcends the struggle for justice within the empirically given rules of social organisation and discourse is impossible... critical thinking is the fundamental precondition for an autonomous and self-motivated public or citizenry" (Aronowitz 1977). At heart, critical education is a process of cultivating consciousness for reason, action and social justice. From this perspective, being conscious 'is a radical form of being' (Freire 1978) in which education helps learners to understand the oppressive systems around them, to critically analyse their situation, and to link theory and action for positive change.

Education for critical consciousness, reflexive reasoning, ethical action, and justice is needed more than ever today in an era where people and planet are confronted with profound threats. Developing a critical awareness of the unfolding ecological, economic, social, political, and cultural crises is essential. But this is not enough in and by itself. We need a shift in thinking amongst all learners to better understand the root causes of these interrelated crisis, and not just see the more immediate reasons for a financial crisis, an ecological disaster, the rise of the far right and xenophobia, or farmer suicides. The articles in this symposium thus address what we refer to as a 'learning for transformation' which aims to construct a critical education and nuanced engagement with underlying causes to advance possibilities for deep change. This iterative process of learning provides the basis for collective action and social change.

A commitment to critical education is key for the future of food and agriculture and social transformation. Indeed, critical learning may be a prerequisite for deepening the transformative vision and praxis of social movements. For example, as the momentum for agroecology as an alternative paradigm for food and farming grows, so have the risks of co-optation and re-alignment with productivist, neoliberal and corporate-controlled farming (Anderson et al. 2019; Giraldo and Rosset 2018; Rivera-Ferre 2017; Pimbert 
2018a). Critical education is, more than ever, necessary to understand how to stay rooted in a transformative perspective for food, agriculture, and human values. An education for critical consciousness can also help create linkages and solidarities between different social movements by fostering new dialogues that reach across boundaries in meaningful ways. Such an educational process may indeed be required to create synergies across movements struggling for food sovereignty (https://viacampesina.org), environmental justice (https://ejatlas.org), feminisms (https://womensmarchglob al.org/), climate justice (https://climatejusticeaction.net), degrowth (https://degrowth.org) or racial justice (https://black livesmatter.com)_for example.

\section{The where: education for transformation in, between and beyond formal and informal spaces of learning}

Where is learning for transformation occurring? Where is it situated? Learning for transformation is based on reflexive action that confronts and dismantles oppression. This contrasts with most approaches to education where learning is oriented towards understanding and adapting behavior within and according to the dominant system (Giroux 2013). Transformative education thus takes place in reference to, but also within and against, dominant power relations and structures that shape the nature of learning and education. The question of where such education processes take place is then not only a matter of cartesian geography (e.g. rural, urban, in Latin America, in Cairo). It is also contingent on relations and spatialities of power. The where of learning for transformation is defined in its relation to power-occurring within, beyond, in reaction to, as a counterpoint, at the margins of, or in the face of various systems that generate social and ecological injustices. It thus takes place wherever agency, power and social change are being claimed by the marginalised through processes of critical learning (Freire 1970; Hooks 1997).

Learning is often discussed in relation to a binary between formal and informal learning spaces or sectorsand research on adult education in food movements often focuses on one or the other. In the informal sector for example, peasant networks in Central America and Cuba (Campesino a Campesino), the landless workers movement in Brazil (MST), the European Coordination of La Via Campesina (ECVC), and indigenous groups in Mexico are systematizing learning programs autonomously from any formal institutions (Anderson et al. 2019; Barbosa 2016; Meek et al. 2019; McCune and Sánchez 2019). These initiatives and programs are often led by farmer- and citizen- educators. In many cases they have emerged to address the lack of appropriate opportunities in formal education and extension which mostly promote Green Revolution approaches and devalue local and traditional knowledges. In many cases, these grassroots initiatives are also an intentional political response against mainstream education which is viewed as deficient and an expression of imperialist hegemony. In contrast, education for transformation involves developing pedagogies that are rooted in the cosmovisions, interests, and political situations of the oppressed in order to build social movements and social change.

In the formal sector, several programs on agroecology, food sovereignty and social transformation do exist. To different degrees, these programs are situated more squarely within the dominant system, close to centres of intellectual, political and economic power. These programs have substantial resources. They are often enjoy wider credibility within the dominant system as institutions of 'higher learning' (note "the where"= above). However, there are few programs in the formal sector that are substantially embedded,- - or even marginally connected to-, wider processes of social transformation based on agroecology and food sovereignty. Most university programs and their pedagogies are shaped by the wider political economy that values and emboldens neoliberal-commercialisable knowledges and elite knowledge systems, and mainly perpetuate and further entrench the status quo (People's Knowledge Collective 2017).

On the other hand, despite the many disincentives and pressures that undermine attempts to enable learning for transformation within formal education (Anderson 2019), there are impulses, actors and programs - often in the margins of academia-which are more closely aligned with social movements and the politics of collective transformation (see: Borras 2016; Levkoe et al. 2018; Méndez et al. 2015). These programs and people are guided by a commitment to community engaged learning and research, traditions of participatory action research, or more general commitments to the wellbeing of marginalised peoples in and beyond their locale. In this regard, programs like the university training program presented in this issue by López-García et al. (2019), provide examples of university anchored programs that can help to promote agroecological transitions in territories.

Formal programs are much more likely to reflect a learning for transformation when they work with social movements. Organisations promoting food sovereignty have in some cases intentionally engaged in adult learning collaborations with post-secondary educational institutions. Here, the intention is to centre knowledge from the margins of society in the institutions of elite knowledge production. Rebecca Tarlau's (2019) recent book demonstrates the important role that the Landless Farmers Movement (MST)'s work on educational reform in Brazil has played as one of multiple repertoires of action in a wider social change strategy. The work of the MST shows how social movements have the capacity 
to implement their own pedagogical programs inside the formal schooling system(s), even under contradictory and often hostile conditions.

However, mainstream approaches and attitudes to education have historically served to perpetuate and re-entrench the status quo along with its dominant ideology. Althusser (1984) described education as an ideological state apparatus, in this case preparing students to accept and conform with the dominant food regime. Much more work is needed to understand how power imbalances can be addressed when mainstream institutions-with their expert cultures, academic priorities and neoliberal economics and incentive structures (Anderson 2019; Pimbert 2018b)—partner with social movement organisations and actors.

A critical learning approach for social transformation transgresses the binary divide between informal-formal education. Different pedagogical methods and tools are used in diverse contexts. But these different pedagogical processes are united by a worldview and a political commitment that consider all spaces of interaction as sites of learning where pedagogy can be used and developed in an iterative and reflexive way. In the context of food and agriculture, this includes spaces of exchange (e.g. shops, markets), in families, schools, libraries, pubs and the multitude of spaces in everyday life. Incorporating this commitment to critical adult learning goes beyond the usual conceptions of lifelong learning as an individualistic and self-referential refrain. Instead, it positions critical learning as a collective and all encompassing mode of social learning, activism and change. In this sense, all spaces and all interactions have pedagogical value that can be intentionally amplified.

Learning for transformation is then made up of individual and collective agency which works across fluid, subterranean, rhizomatic processes that manifest concretely in planned moments as well as at times of spontaneous learning. Learning for transformation transgresses any fixed categorisation or prescription of where education should take place and of who is qualified to be a teacher in any place versus another. Once an individual or organisation sees themselves in this light, and views all moments as having pedagogical value (for teaching-learning), the division between formal and informal spaces of learning becomes less important and less constricting. The division between who is a teacher and who is a student also begins to dissolve, as shown in different schools in Latin America (Meek et al. 2019; McCune and Sánchez 2019) and Spain (Casado Baides 2018). In this formulation, the 'where' of learning for transformation is normatively, "everywhere" and by everyone.

Learning for transformation is a fundamentally subversive process in that it seeks to contribute towards just societal transformation. Education, in this regard, is deliberately and explicitly political: not an education about—but an education for-normative visions of change such as food sovereignty, social justice or emancipation. In terms of the question of "the where" then, it is important to remember that it is also a question of "where to". The focus on transformation recognises that where we are today is not where we should be in the future. Learning and pedagogy are viewed as important approaches to gaining collective agency and determining the pathway(s) of emancipation.

In this regard, not all food systems education reflects an approach that contributes to a learning for transformation. Indeed in many cases, education that is deemed to be 'progressive' or 'for food sovereignty' can inadvertently be apolitical, de-politicising or de-mobilising if it fails to develop the political consciousness and actions needed for social transformation. For example, many NGOs, governments and even social movement initiatives engage learners as individuals, focusing on proximate (rather than deep systemic) analysis of political problems. Or even more problematic, they construct learning for transformation as a process of only acquiring new skills as individual consumers. In some cases, it is possible that these actors have a radical sense of the "where to". But their understanding of "the how" in regards to learning and education either lacks depth and critical thought or the capacity and skills to follow a transformative path. As evident across the articles in this issue, learning for transformation requires a deeply political pedagogy that transcends individuals. It is concerned with the wider 'how' of emancipatory learning and collective processes of change. Indeed, a commonality across all of these contributions is an emphasis on documenting, developing, and theorizing "the how"- that is the pedagogical processes that underpin an education for food sovereignty and food systems transformation.

\section{The how: pedagogical underpinnings of learning for transformation}

The seven articles in this special issue highlight new thinking on how, - and under what conditions-, can pedagogies for food sovereignty and agroecology contribute to a community's political and physical control over food systems and the governance of their territories (Meek and Tarlau 2016). Many of the articles articulate and further elaborate some long standing principles of critical pedagogy, horizontal learning, transformative learning and other related traditions. We encourage readers to work through the articles to get a sense of how these approaches are being developed in different contexts and regions including Africa, North America, South America, Europe and Asia. In the following sections, we emphasise five important areas to consider when reading across the seven papers. 


\section{The political economy of education: a shift from a commercial and individualised entrepreneurial model of training to a commitment to education for solidarity and care}

Many of the articles demonstrate how the political economy of education shapes the potential of a learning for transformation approach. Massicotte and Kelly-Bisson (2019) examination of permaculture training in Eastern Ontario (Canada) for example illustrates how the individualised entrepreneurial tendencies that predominate in permaculture training undermines the emancipatory potential that is ostensibly written into the permaculture approach. They argue that widespread access to permaculture knowledge and skills today is limited because it depends on payment for certified training courses led by expert trainers in a market-led approach to education. In this case, the wider political economic context of western capitalism and neoliberalism has shaped the delivery and scope of teaching and educational programs, thereby reducing its initial transformative potential. As a result, permaculture design trainers in Canada "have tended to function as technical trainers from affluent social backgrounds without an explicit intention of participating in a transformation of agri-food systems" (Massicotte and Kelly-Bisson 2019).

In another article in the special issue, McCune and Sánchez (2019) explain how the influence of western NGOs in a period of neoliberal development reshaped the Peasant-to-Peasant approach in Nicaragua away from one based on mutual-aid. A service-provision and market led approach emphasized paid training courses to teach peasants to become service providers through ecotourism and other commercial activities. Both Massicote and Kelly-Bisson as well as McCune and Sánchez draw a contrast between these kinds of individualist pedagogies with an education for solidarity. They use examples from Brazil and Cuba to emphasise the potential of an educational model based on alternative political economic relations and imaginaries. They reject capitalist values and modes of educational production as the basis of meeting the material and intellectual needs of instructors and activists-learners-farmers. The enactment of prefigurative post-capitalist forms of exchange and mutual support creates new possibilities that are otherwise systemically suppressed.

Meek et al. (2019) discuss the issue of dependence of grassroots educational programs on external funding, and how this undermines more radical pedagogies. They ask to what extent can funding, institutionalization (or the institutional environment) and/or the relation with the state compromise the emancipatory nature of these experiences. This is a common situation in social movements where the absence of funds often stimulates creativity and collective work. In contrast, the availability of substantial funds can reduce levels of grassroots voluntary work and initiatives by hiring external technical staff. This can subsequently undermine collective work, unless the recruited staff are well trained in facilitating cooperative group processes based on clear commitments to change. As Meek et al. (2019) state, "institutionalization can be the death knell for critical food systems education", where transformative aims are eroded or sidelined through funding and reformist actions supported by the state, philanthropic donors, or other actors aligned with the dominant regime.

The decommodification of education - and resisting commodification in the first place - can open new possibilities for solidarity-based and politicized learning programs that are accessible to all,-—including indigenous peoples, women, as well as other subaltern and oppressed groups. Embedding this solidarity in social movements in ways that strengthen organisations, networks, radical visions and alternative identities (Anderson et al. 2019) helps sustain the practices in which a solidarity economy of education can grow.

\section{A critical pedagogy that values organic intellectuals}

Contributors to this special issue affirm the importance of organic intellectuals and educator-trainers in enabling mutual learning for political organizing and knowledgebuilding. According to Gramsci, organic intellectuals emerge organically from a particular social-political class and play a critical role as facilitator-organisers of counter-hegemonic struggles. They often act as educators, helping to construct and translate counter-hegemonic theory into educational praxis to nurture class consciousness in social movements (Ramos 1982). The role of organic intellectuals as educator is essential to achieve unity of theory and practice. By linking the abstract and the concrete, organic intellectuals and educators can foster a counter-hegemonic movement capable of contesting the dominant agri-food regime. In this regard, the articles reveal two critical components of a learning for transformation: (i) every person has the capacity to act as an 'intellectual' and indeed to foster and realise this capacity; and (ii) it is from the oppressed, and through the leadership of organic intellectuals, that transformative knowledges can emerge.

These two elements are linked and can overlap, but we differentiate them because they have different outcomes in education for food sovereignty. The first one favours agroecological education because it implies that facilitatoreducators as organic intellectuals need to be humble, avoid vanguardist tendencies, and strengthen collective forms of intelligence through horizontal approaches to learning. This approach is rooted in a recognition that counter-hegemonic leadership is strongest when distributed, when intellectual power is collectivized, and when the inherent intellectual capacities of the oppressed are cultivated equally. 
The second important characteristic is that it is from "the oppressed" people that knowledge for social transformation can emerge. Gramsci believed that an emancipatory project should emerge from marginalised communities becoming conscious of the multiple oppressions they may suffer, and by organising themselves (Massicotte and Kelly-Bisson 2019). This is in fact how political alternatives like food sovereignty were born. It is indeed from marginal groups that new knowledges may emerge in future. This view also coincides with feminist theory which argues that the marginalised and oppressed have the knowledge and experience needed to understand and confront their own problems (Truman et al. 2005; Brown and Strega 2015).

Gramsci's concept of "organic intellectuals" is key in this process of fundamental change. Organic intellectuals emerge from within a particular class, - - middle or working class, - they are recognised by the people of this class, and they take on the role of "specialized" intellectuals capable of fostering a sense of self-awareness among members of their class. Typically, organic intellectuals work to mobilise and politicise within their respective communities to catalyse, facilitate, and support deep cultural and socio-political change,--from the bottom-up.

It is noteworthy that organic intellectuals and other facilitator-trainers must not only have the appropriate knowledge and skills to train others. Organic intellectuals and other educators for food sovereignty also need to cultivate enabling attitudes and human qualities such as humility and empathy to work with the most marginalised sectors of society. Indeed, McCune and Sánchez (2019) argue that, "Human qualities such as humility, honesty, integrity and solidarity are considered as important to the learning process as are composts, intercropping, and seed saving".

\section{An emphasis on collective learning and cooperation}

Learning for transformation is not an individualistic endeavour. It is based on an intentional collectivity in organisations, programs, and affinity groups as well as in emergent networks of people linked through bonds of reciprocity, mutual aid, and communication. Collective processes, such as horizontal farmer-to-farmer exchanges, diálogos de saberes, and cooperation allow agroecological knowledge to be shared, documented, discussed, built and mobilized on a large scale, connecting many people and places (Anderson et al. 2019; McCune and Sánchez 2019; Mann 2018). These processes recognise that when learning is conceived as an individual endeavour, this often gives rise to individualistic subjectivities and parochial self-interested understandings. In turn, this undermines possibilities for transformation.

Collective learning dynamics fundamentally challenge the conventional view that "learning is an individual process that takes place in one human mind at a time" (McCune and
Sánchez 2019). Anderson et al. (2019) argue that collective processes of learning are themselves an act of resistance against the individualising tendencies of the dominant neoliberal mode, and are thus critical for societal transformation. In this regard, it is often the informal learning spaces,- - embedded in communities, networks and social movements,-where collective learning is most viable. This is largely because the learning dynamic is rooted outside the individualising nature of 'individual excellence', individual grading and individualised systems of meritocracy found in schools, universities and many workplaces.

The process of building enabling educational environments that adopt a collectivist mindset is therefore extremely important in transformative education (Casado Baides 2018). The educational environment involves intentionally structuring learning where students and learners are mutually a part of,- - and responsible for,- - building the community. This includes taking care of each other, creating a governance structure and rules for decision-making, as well as developing conviviality and a shared culture within the learning environment. This approach, however, takes time and often requires negotiating differences in a group. While challenging, these 'edges' between people, perspectives and worldviews create the conditions for deep learning that extends beyond the boundaries determined by a more individualistic and self-centred learning approach. Articles of this volume (McCune and Sánchez 2019; Meek et al. 2019) highlight the importance of the educational environment, in which students are part and responsible of the process of building community.

\section{A focus on intersectionality}

Overcoming the enduring and interconnected systems of economic, racial, colonial and gender oppressions,- and the violence that maintains them,- -is another major challenge for emancipatory pedagogies. The design of learning for agroecology and food sovereignty is often based on an analytic framework that tries to identify how interlocking systems of power impact those who are most marginalized in society. A pedagogical praxis that is sensitive to issues of intersectionality works to address the complexities of power and inequality through a complex understanding of how people interact in learning spaces at the intersection of multiple axes of difference (e.g. gender, class, race, age, religion, sexual orientation, and disability). Pedagogical approaches that impose pre-existing and universal framings of oppression and political struggle can alienate learners whose experiences reflect distinct trajectories, identities and positionalities. An intersectional approach can create important opportunities for learning, solidarity and change across these diverse experiences and identities. 
Bezner Kerr et al. (2019) describe how a focus on intersectionality and social inclusion guided the development of an innovative curriculum for agroecology in Malawi and Tanzania. Aimed at smallholders, the learning process was participatory and built on popular education, feminist praxis, experiential-based pedagogies, and theatre. As this critical pedagogical process strived to coherently weave together technical components (agroecology, climate change, soil nutrition....) it also had to sensitively engage with clashes of language, cultural norms, and terminology that reflected differences in gender and other axes of difference (Bezner Kerr et al. 2019). In another example from Canada, the excluded voices of migrant hired farm workers were foregrounded through a praxis of community-based arts (Perry 2019), primarily rooted in Augusto Boal's techniques of collective theatre creation (Boal 1985). This allowed participants to express and discuss their experiences of oppression. Plays created and performed by migrant farm workers made it possible to explore difficult issues related to intersectionality, such as deeply uneven power relations in the workplace, co-worker harassment, and loneliness.

By focusing on various intersections of social inequality as the matrix of domination (Collins 1990), critical pedagogical processes and methodologies can thus help de-stabilise and overcome interlocking vectors of oppression and hegemonic power in food and agriculture.

\section{Regenerating territories through popular education}

Large-scale programs of learning for transformation are most impactful when they embed collective learning in wider processes of territorialisation within radical frameworks such as agroecology and food sovereignty-or broader mobilising concepts like Buen Vivir. Thus, a process of territorialisation seeks not only to regenerate sustainable farming and agroecosystems and other parts of the food system (e.g. farmer seed networks, mills, dairies, community food processing facilities...) but also the territorial relations and infrastructure required to meet human needs and generate local livelihoods (e.g. schools, health clinics, community centers, cooperatives, small scale industry...). Learning for transformation thus knits together the humanecological relations within territories that have often been stripped of their cultures, people, resources, and autonomy through centuries of capitalism and colonialism (Massicotte and Kelly-Bisson 2019).

Learning for transformation as a process of re-territorialisation is simultaneously immaterial and material (Giraldo and Rosset 2018). It involves learning cycles of both action and theory that simultaneously work to challenge ongoing processes of capitalist de-territorialisation whilst reflexively constructing alternatives. For example, learning programs can unpack and explore immaterial notions of solidarity in economic exchange. In so doing, they can re-invent new forms of modernity and well-being within their own specific territories while supporting the material project of developing alternative systems of economic exchange to exit unfair commodity markets (Pimbert 2018c). Thus, McCune and Sánchez (2019) show how, "As pedagogical processes develop, new territorial dynamics take shape, revealing that self-organized peasant education contributes to sustaining popular territories against the aggression and violence of globalized capital." Processes of "territorial learning" strengthen local organisations and wider social movements (Anderson et al. 2019), thereby enabling learners to become transformative agents of their own reality. LópezGarcía et al. (2019) describe a process of "agroecological dynamisation" that reflects this territorial approach, arguing that universities, under the right conditions and commitments, can play a role in mobilizing a wide diversity of actors (educators, farmers, consumers, policy-makers, etc.) to strengthen the social fabric in a territory.

\section{The what next: new frontiers for education for and beyond food sovereignty}

The papers in this issue, and our collective process of putting together the special issue as a team, have surfaced several unresolved questions and potential frontiers for learning for transformation. We share these here to prompt further thought on the "what next" for extending, deepening, and strengthening pedagogic praxis for transformative learning in struggles for food sovereignty and social justice.

Food sovereignty is, in theory, an emancipatory approach to framing and pursuing societal transformations. Yet, in many cases, the networks and practices of food sovereignty, agroecology, local food, permaculture, reproduce inequities and power differentials (People's Knowledge Collective 2017). Whilst there have been efforts to advance a theory of education for food sovereignty, including in this special issue, one of the yet to be explored frontiers is the extent to which popular education initiatives in different contexts are advancing emancipation for the most marginalised and oppressed. Recent work on the links between gender and agroecology in Brazil's landless farmers movement (Schwendler and Thompson 2017), indigenous education (Goulet and Goulet 2014), and decolonial pedagogy (Wane and Todd 2018) point to further research needed to deepen our understanding of the politics of learning for transformation.

We also found ourselves reflecting on the notion of a diálogo de saberes ("dialogue of knowledges") and to what extent this dialogue can effectively take place between actors who believe in food sovereignty or other radical causes on the left with those that have other, and in some cases deeply 
conflicting politics (neoliberals, far-right). We desperately need to develop approaches that go beyond learning amongst like-minded and politically aligned actors. Bringing together individuals and groups with different views and positionalities can help to better understand difference, identify common experience, develop empathy, transform conflict, and unearth the roots of oppression. These dynamics are not often visible on the surface but can be deduced and strengthened through deep and critical collective learning. Is it possible that such learning processes could help raise critical consciousness and acceptance of difference? Can they help avoid authoritarian tendencies in populist movements struggling for food sovereignty, 'radical political agroecologies' (Cadieux et al. 2019) or degrowth (D'Alisa et al. 2014)? Further work is needed to understand how pedagogy can help to cross these deepening divisions in society.

We also found ourselves asking how critical education helps enable and politicize a process of broader awakening and organising for social transformation? For example, the concept of "quiet sustainability" or "quiet food sovereignty" has been used to express a politics of sustainability that is performed through the enactment of sustainable lifestyles by actors that are not intentionally nor overtly politicized (Visser et al. 2015; Kneafsey et al. 2017). While these practices may enact sustainable behaviors and practices, they do nothing to reveal and address the underlying systems of oppression that are left intact and unquestioned. They also tend towards individualistic tendencies that run counter to the collectivist nature of learning for transformation articulated in this special issue. Finally, arguing for such passive approaches to sustainability could be said to come from a place of privilege (who has the privilege to make lifestyle choices?). To us, learning for transformation is a direct challenge to such de-politisised subjectivities. Encouraging a wider critical awakening is urgently needed today given the violence, inequality and potential ecological collapse in territories as well as possibly larger and even planetary scales. More work is needed to understand how learning for transformation can reach beyond the already-politicised,- to meet people where they are (e.g. peasants and consumers practicing what is referred to as quiet sustainability), and draw people together in collective processes of learning tied to the territorial and global processes of social movements.

Answering these questions may require crossing boundaries and consciously hybridising the insights and practices of other traditions of emancipatory education outside and beyond food sovereignty. For example, much can be learnt from radical, critical, indigenous, feminist and anarchist pedagogies for collective learning and action that address internal power dynamics of movements. Radical critical pedagogy (Mclaren 1997) and participatory action research (Wakeford and Rodríguez 2018) offer ways of moving food sovereignty/justice into a more reflexive space.
Similarly, ideas and practices traditionally associated with social anarchism have repeatedly emphasised the importance of education for social transformation. Exploring the neglected traditions of anarchist education in Spain, France, UK and the USA, Suissa (2006) shows the extent to which social anarchists are committed to a radical and substantive educational process based on clear moral principles. Anarchists affirm the right of individuals to be "active agents creating the possibilities for their own future" (McKenna 2001, p. 52). In turn, this calls for a deeply transformative education based on freedom for creative experimentation, critical thought, and active problem solving. As Bookchin (1990, p. 189) notes:

Sensibility, ethics, ways of building reality, and selfhood have to be changed through educational means, by a politics of reasoned discourse, experimentation and the expectation of repeated failures from which we have to learn, if humanity is to achieve the selfconsciousness it needs to fully engage in self-management.

More generally, the new frontiers for food sovereignty and beyond will need to prioritise an 'education for radical democracy' (Amsler 2015) with its wealth of critical tools and practical methods. By emphasising a politics of possibilities, these pedagogies of hope can help cultivate counter-capitalism, resistance to domination, a non hierarchical sensibility, practices of freedom, as well as radical alternatives grounded in environmental and social justice.

\section{Conclusion}

In this editorial overview, we introduced the concept of learning for transformation, unpacking the seven articles in the special issue to make sense of the why, where (and where to), how, and what next? While these have been useful for making sense of the collective contribution of these articles and how they are situated in the literature, we assert that it is important also for practitioners to ask themselves these questions of their own pedagogical practice and programs. The responses to these questions in particular places and situations are context specific and will evolve over time. By asking ourselves these questions, and debating the nature and dynamics of our learning and education programs, we can iteratively develop a pedagogy that is simultaneously more radical, transformative, and more effective. To this end, we invite you to connect with us and with each other as critical friends with a mutual commitment to learning for a more just and sustainable world. ${ }^{1}$

\footnotetext{
1 Two spaces convened by two of the authors (Pimbert and Anderson) offer opportunities to connect with a community of practice/ praxis working to develop a space of collective reflexivity and learn-
} 


\section{References}

Althusser, L. 1984. Ideology and ideological state apparatus. In essays on ideology. London: Verso.

Amsler, S.S. 2015. The education of radical democracy. London: Routledge.

Anderson, C.R. 2019. Becoming a public scholar in the professional academy: Confronting the institutional, interpersonal and internalized dimensions of (re)professionalisation. ACME: An International Journal for Critical Geographers.

Anderson, C.R., C. Maughan, and M.P. Pimbert. 2019. Transformative agroecology learning in Europe: building consciousness, skills and collective capacity for food sovereignty. Agriculture and Human Values. https://doi.org/10.1007/s10460-018-9894-0.

Anderson, C.R., J. Bruil, M.P. Pimbert, J. Chappell, C. Kiss, and J. Milgroom. Forthcoming. Agroecology now! The battle for the future of food.

Aronowitz, S. 1977. Mass culture and the eclipse of reason. The implications for pedagogy. College English 38: 768-774.

Barbosa, L.P. 2016. Educação do Campo [education for and by the countryside] as a political project in the context of the struggle for land in Brazil. The Journal of Peasant Studies 44 (1): 118-143.

Bezner Kerr, R., S.L. Young, C. Young, M.V. Santoso, M. Magalasi, M. Entz, E. Lupafya, L. Dakishoni, V. Morrone, D. Wolfe, and S.S. Snapp. 2019. Farming for change: developing a participatory curriculum on agroecology, nutrition, climate change and social equity in Malawi and Tanzania. Agriculture and Human Values. https://doi.org/10.1007/s10460-018-09906-x.

Boal, A. 1985. Theatre of the oppressed. New York: Theatre Communications Group.

Bookchin, M. 1990. Remaking society. Pathways to a green future. Boston, MA: South End Press.

Borras, S.M. 2016. Land politics, agrarian movements and scholaractivism. Inaugural Lecture, 14. International Institute of Social Studies. https://www.tni.org/files/publication-downloads/borras_ inaugural_lecture_14_april_2016_final_formatted_pdf_for_print ing.pdf.

Brown, L., and S. Strega (eds.). 2015. Research as resistance, $2 e$ : Revisiting critical, indigenous, and anti-oppressive approaches, 43-64. Toronto: Canadian Scholars' Press.

Cadieux, K.V., S. Carpenter, A. Liebman, R. Blumberg, and B. Upadhyay. 2019. Reparation ecologies: Regimes of repair in populist agroecology. Annals of the American Association of Geographers 109 (2): 644-660. https://doi.org/10.1080/24694452.2018.15276 80.

Casado Baides, B. 2018. Procesos de formación de campesinos y disputa territorial para construir soberanía alimentaria. Análisis de experiencias impulsadas por organizaciones de La Vía Campesina en Brasil y País Vasco. PhD Thesis. University of Basque Country.

Collins, P.H. 1990. Black Feminist thought: Knowledge, consciousness, and the politics of empowerment. Boston: Unwin Hyman.

D’Alisa, G., F. Demaria, and G. Kallis. 2014. Degrowth: A vocabulary for a new era. London: Routledge.

Freire, P. 1970. Pedagogy of the oppressed. Harmondsworth: Penguin.

Freire, P. 1978. Pedagogy in process: The letters to Guinea-Bissau. New York, London: Continuum.

Footnote 1 (continued)

ing as critical friends. www.peoplesknowledge.org and www.agroe cologynow.com.
Giraldo, O.F., and P.M. Rosset. 2018. Agroecology as a territory in dispute: Between institutionality and social movements. The Journal of Peasant Studies 45 (3): 545-564.

Giroux, H.A. 2013. On critical pedagogy. New York and London: Bloomsbury Academic.

Goulet, L.M., and K.N. Goulet. 2014. Teaching each other: Nehinuw concepts and Indigenous pedagogies. Vancouver: UBC Press.

Hooks, B. 1997. Teaching to transgress. London: Routledge.

Kneafsey, M., L. Owen, E. Bos, K. Broughton, and M. Lennartsson. 2017. Capacity building for food justice in England: The contribution of charity-led community food initiatives. Local Environment 22 (5): 621-634.

Levkoe, C.Z., J. Brem-Wilson, and C.R. Anderson. 2018. People, power, change: Three pillars of a food sovereignty research praxis. The Journal of Peasant Studies. https://doi.org/10.1080/03066 150.2018.1512488.

López-García, D., L. Calvet-Mir, M. Di Masso, and J.L. Espluga. 2019. Multi-actor networks and innovation niches: university training for local Agroecological Dynamization. Agriculture and Human Values. https://doi.org/10.1007/s10460-018-9863-7.

Mann, A. 2018. Education for food sovereignty as transformative ethical practice. Policy Futures in Education. https://doi. org/10.1177/1478210318816251.

Massicotte, M.J., and C. Kelly-Bisson. 2019. What's wrong with permaculture design courses? Brazilian lessons for agroecological movement-building in Canada. Agriculture and Human Values. https://doi.org/10.1007/s10460-018-9870-8.

McCune, N., and M. Sánchez. 2019. Teaching the territory: agroecological pedagogy and popular movements. Agriculture and Human Values. https://doi.org/10.1007/s10460-018-9853-9.

McKenna, E. 2001. The task of Utopia. A pragmatist and feminist perspective. Maryland: Rowman and Littlefield Inc.

McLaren, P. 1997. Revolutionary multiculturalism. New York: Routledge.

Meek, D., and R. Tarlau. 2016. Critical food systems education (CFSE): Educating for food sovereignty. Agroecology and Sustainable Food Systems 40 (3): 237-260.

Meek, D., K. Bradley, B. Ferguson, L. Hoey, H. Morales, P. Rosset, and R. Tarlau. 2019. Food sovereignty education across the Americas: multiple origins, converging movements. Agriculture and Human Values. https://doi.org/10.1007/s10460-017-9780-1.

Méndez, V.E., C.M. Bacon, R. Cohen, and S.R. Gliessman. 2015. Agroecology: A transdisciplinary, participatory and action-oriented approach. Boca Ratón, London and New York: CRC Press.

People's Knowledge Editorial Collective (Eds). 2017. Everyday Experts: How people's knowledge can transform the food system. Reclaiming Diversity and Citizenship Series. Coventry: Coventry University. http://www.coventry.ac.uk/everyday-experts.

Perry, J.A. 2019. Images of work, images of defiance: engaging migrant farm worker voice through community-based arts. Agriculture and Human Values. https://doi.org/10.1007/s10460-018-9861-9.

Pimbert, M.P. 2018a. Global status of agroecology, a perspective on current practices, potential and challenges. Economic and Political Weekly 53 (41): 52-57.

Pimbert, M.P. 2018b. Democratizing knowledge and ways of knowing for food sovereignty, agroecology and biocultural diversity. In Food sovereignty, agroecology and biocultural diversity. Constructing and contesting knowledge, ed. M.P. Pimbert, 259-321. Londo: Routledge.

Pimbert, M.P. 2018c. Food Sovereignty and the regeneration of terraced landscapes. Annales, Series Historia and Sociologia 28 (4): 779-794.

Ramos Jr., V. 1982. The concepts of ideology, hegemony, and organic Intellectuals in Gramsci's Marxism. Theoretical Review 30: 34.

Rivera-Ferre, M.G. 2017. The resignification process of agroecology: Competing narratives from governments, civil society and 
intergovernmental organizations. Agroecology and Sustainable Food Systems 42(6): 666-685.

Schwendler, S.F., and L.A. Thompson. 2017. An education in gender and agroecology in Brazil's Landless Rural Workers' Movement. Gender and Education 29 (1): 100-114.

Suissa, J. 2006. Anarchism and education. A philosophical perspective. London: Routledge.

Tarlau, R. 2019. Occupying schools, occupying land: How the landless workers movement transformed Brazilian education. Oxford: Oxford University Press.

Truman, C., D.M. Mertens, and B. Humphries. 2005. Research and inequality. London: UCL Press, Taylor \& Francis Group.

Visser, O., N. Mamonova, M. Spoor, and A. Nikulin. 2015. 'Quiet food sovereignty' as food sovereignty without a movement? Insights from post-socialist Russia. Globalizations 12 (4): 513-528.

Wakeford, T., and J. Sánchez Rodríguez. 2018. Participatory action research: towards a more fruitful knowledge' In Connected Communities Foundation Series, ed. Facer, K. and K. Dunleavy. Bristol: University of Bristol/AHRC Connected Communities Programme. https://connected-communities.org/wp-content/uploa ds/2018/07/Action_Research_SP.pdf.

Wane, N.N., and K.L. Todd (eds.). 2018. Decolonial pedagogy: Examining sites of resistance, resurgence, and renewal. Cham: Springer.

Publisher's Note Springer Nature remains neutral with regard to jurisdictional claims in published maps and institutional affiliations.

C. R. Anderson is a Senior Research Fellow at the Centre for Agroecology, Water and Resilience, Coventry University. His research focuses on community- and people- led processes of transformation for resilience, social justice and well-being. He works with communities, networks and organizations who are addressing the multitude of social, economic and cultural problems we face today and who are reimaging society and building alternatives. His collaborative research contributes to the development of thinking and action related to food systems, community building, food sovereignty, activism, and knowledge mobilization, and especially focuses on the workings of power, resilience, and regeneration in these areas. Visit www.agroecologynow.com and www. peoplesknowledge.org to find out more.
R. Binimelis holds a $\mathrm{PhD}$ in Environmental Science (Ecological Economics). She works as a researcher at the Chair in Agroecology and Food Systems and the research group "Societies, Policies and Inclusive Communities" at the University of Vic. Her research fields deal with the analysis, from a multidisciplinary perspective, of agri-food systems and socio-environmental conflicts. She is specialized in analysis of socio-economic impacts of GMOs and is interested in examining the social, cultural, political, ecological and economic implications of the ways food is perceived, produced and consumed. She has also worked on food sovereignty and gender, agroecology and alternative food systems. Rosa is now coordinating a network for food sovereignty in Central Catalonia (XaSACC).

M. P. Pimbert is Professor of Agroecology and Food Politics at Coventry University and the Director of the Centre for Agroecology, Water and Resilience in the UK. His research interests include agroecology and food sovereignty; the political ecology of biodiversity and natural resource management; participatory action research methodologies; and deliberative democratic processes. He works with networks of small and family farmers, indigenous peoples, and communities to advance transdisciplinary and transformative ways of knowing that regenerate local ecologies, economies and cultural diversity.

M. G. Rivera-Ferre is a Ramón y Cajal Research Fellow at the University of Vic-Central University of Catalonia. She coordinates the research line "Sustainable communities, social innovations and territories" within the group "Inclusive societies, policies and communities" and is director of the Chair Agroecology and Food Systems for Social Transformation. With a multidisciplinary profile in the analysis of social and ecological interactions of agri-food systems, she has a particular interest in alternative agri-food networks following the food sovereignty paradigm and in the analysis of feminists and commons theories as to be adopted in agri-food research. She has worked on the potential of local traditional agri-food knowledge in transformative adaptation to climate change. Marta has participated as lead author in the International Assessment of Agricultural Knowledge Science and Technology for Development (IAASTD) and the Intergovernmental Panel on Climate Change (IPCC). 